Jurnal Pendidikan Bahasa dan Sastra, Volume 19, Nomor 2, Oktober 2019, pp. 211 - 219

p-ISSN 1412-0712, e-ISSN 2527-8312, doi: https://doi.org/10.17509/bs_jpbsp.v19i2.24786

\title{
Transformation of a Novel Murder on The Orient Express into its Film Adaptation using Ecranization Study
}

\author{
Yogy Aspriyanto, \& Erni Hastuti \\ Department of English Literature, Universitas Gunadarma \\ yogiias888@gmail.com; erni@staff.gunadarma.ac.id
}

How to cite (in APA Style): Aspriyanto, Y., \& Hastuti, E. (2019). Transformation of a Novel Murder on The Orient Express into its Film Adaptation using Ecranization Study. Jurnal Pendidikan Bahasa dan Sastra, 19(2), 211-219. DOI: https://doi.org/10.17509/bs_jpbsp.v19i2.24786

Article History: Received (19 August 2019); Revised (02 September 2019); Accepted (1 October 2019). Journal homepage: http://ejournal.upi.edu./index.php/BS_JPBSP

\begin{abstract}
The objectives of this research are to determine and analyze the ecranization process on the characters in novels and its film adaptation. This research used descriptive qualitative method. The importance of this research can give contribution for other researchers who want to conduct the research about ecranization processes such as addition, reduction and variation of change in terms of plot, character and setting. The research results in the ecranization process on the character occurs reduction, addition and variation of change. The reduction in both novels and films occurs because the duration of the film cannot be long, unlike in a novel with a long duration the film reduced characters, although undergo the reduction but does not omit or change the main of the story. The addition both novels and the film added characters to the film because the director wanted to give a creative impression on some scenes in the film and not monotonous as in the novel. The variation of change both novels and films occurred by the characters that were replaced because the director wanted to make a difference between the novel and the film and also variation of change in the character did not change the main storyline of the novel and the film.
\end{abstract}

Keywords: ecranization; film; novel; reduction; variation of change

\section{Transformasi Novel Murder on The Orient Express Ke dalam Film Adaptasinya dengan Menggunakan Kajian Ekranisasi}

\begin{abstract}
Abstrak: Penelitian ini bertujuan untuk menentukan dan menganalisis proses ekranisasi pada karakter di dalam novel dan adaptasi filmnya. Penelitian ini menggunakan metode kualitatif deskrptif. Pentingnya penelitian ini adalah dapat memberikan kontribusi kepada peneliti lainnya yang akan melakukan penelitian tentang proses ekranisasi seperti pengurangan, penambahan dan perubahan variasi. Hasil dari penelitian ini yaitu proses ekranisasi yang terjadi pada karakter antara lain pengurangan, penambahan dan perubahan variasi. Pengurangan pada kedua novel dan film terjadi karena waktu yang tidak bisa panjang dalam film, tidak seperti dalam novel dengan waktu yang panjang dalam film karakter mengalami pengurangan. Meskipun mengalami pengurangan tapi tidak menghilangkan atau mengubah inti dari ceritanya. Pada penambahan, kedua novel dan film tersebut menambahkan karakter pada filmnya karena sutradara ingin memberikan kesan kreatif pada beberapa adegan dalam film tersebut dan tidak monoton seperti pada novel. Pada perubahan variasi, kedua novel dan film tersebut mengalami pergantian karakter karena sutradara ingin memberikan perbedaan antara novel dan film dan juga perubahan variasi pada karakter tidak mengubah inti jalan cerita pada novel dan film tersebut.
\end{abstract}

Kata kunci: ekranisasi; film; novel; pengurangan; perubahan variasi 


\section{INTRODUCTION}

A film taken from novels become an interesting phenomenon carried out by filmmakers and creates a very high interest for film lovers. This is in line with Corrigan (1999) stated that one estimate claims that 30 percent of films currently originate from novels and that 80 percent of books classified as best sellers have been adapted to the cinema. The purpose of the adaptation can come from actual reading or a literary classic which is replaced by pictures such as a novel with a film process. Some of the titles of works that are taken from novels into film, such as: The Old Man and The Sea by Ernest Hemingway in 1951, Carrie by Stephen King in 1947, The Lord of the Rings by Tolkien in 2000 and etc. The titles of films that have achieved success in the film industry as the main indicator of the appointment of the novel into a film. The filmmaker bold initiative to make films based on literary works, so that the phenomenon of an ecranization appears to pursue the market. The intended market is the license to accompany literary works. Film adaptations appear to have focused on the ways in which a novel is translated into a film focusing on the similarities and differences between them. For that, Darmono in Praharwati and Romdhoni (2015) stated that the novel usually categorized as popular literature, was appointed to the silver screen after being transformed into a screenplay.

The transformation from one literary work such as novel into a film is also often called by an ecranization in which transformation story from novel into film has difference such as the readers should use their imagination to understand the story in the novel, but the viewers should use their sight, enjoying the story by dialogues and expressions the actors or the actresses show to understand the story in the film. McFarlane's (1996) attempts to analyze adaptation are also largely based to analyze adaptations based on a contrast-comparison approach. However, the initial aim was to set different directions, where trying to find literary and film similarities, and the extent to which the two media were exchanged.

According to Nurgiyantoro (2015, p.30), the intrinsic element of a novel is the element that directly participates in building the story. This elements are the unity that makes a novel come true such as: the story, plot, character, characterization, theme, background, point of view, figurative language and moral message. Meanwhile, Pratista, (2008, p.1) stated that Film is a literary work that combines the narrative elements and cinematic elements so that become harmonious entities. A film is made up of two elements, namely narrative and cinematic elements. Narrative elements are related to aspects of stories or film themes. Each story film cannot be separated from narrative elements and each story must have elements such as characters, problems, conflicts, location, time, and others. All of these elements establish the overall narrative element. Cinematic elements are technical aspects in the production of a film that has important elements such as settings, lighting, costumes and make-up, acting and movement of players.

Ecranization can be interpreted as a change in the enjoyment process, namely from reading to watching that can be enjoyed anytime and anywhere into art that is only enjoyed in certain places and at certain times. According to Eneste (1991,p.60), ecranization is transformation or screenization story from a novel into a film and novel have intrinsic elements such as stories, plot, setting, characterization and language style are conveyed in words. Meanwhile, intrinsic elements in the film are conveyed with images and sounds that are moved. For this, it can be said that ecranization is changing the world of words into a world of images and sounds that are moved. In other words, ecranization means the process of an individual produced into something that is produced together. Bluestone (1957) in Istadiyantha (2017) states that the difference in raw materials between 
novels and films cannot be fully explained on the basis of differences in content. Each medium requires a privilege through heterogeneity and overlapping, the condition of audience demand, and its artistic form. In addition, the film-bound factor with duration causes film workers to be creative to sort and select the events that are important to be filmed. Therefore, it is common to see differences and shifts in particular with regard to the story line considering that each has a character that adapts to the function of the media of the work. In the adaptation process contained the concept, conversions, along with the understanding of different characters.

According to Eneste (1991,p.61-65), those processes used to transform the story from novel into film have three processes such as 1). Addition, there are parts that added due to the attractiveness of the story, the character of the plot and setting. Screenwriters or directors have interpreted the novel that they will film so that it will happen additions process in everywhere. This process does not change the essence of both stories; 2). Reduction, in the novel does not reveal everything so that the film will not be found. Part of the story, plot, setting, character and atmosphere of the novel will not be found in the film; 3) variation of change, in ecranization also allows for certain variations where from the novel to the film there are parts that are changed with the intention to attract stories, characters and settings because of the differences in the tools used, in the film also has a very limited play time, so that not all things or problems in the novel can be moved into the film Those processes used to transform the story from novel into film.

Several related studies have been done in this research, Aderia (2012) in his article, which consists of eleven sub-chapters after classification into 112 episodes. This research discussed about the process of ecranization theory, reduction, addition, and variation of change and explained similarities plot and character in the novel into film. This research focused in the term of plot and character that occur in intrinsic elements of theory by using Ecranization Theory and explain the similarities of plot and character. The result concluded that there are similarities and differences of the plot and characters in novel and its film adaptation Surat Kecil Untuk Tuban. Other similar and recent studies in literary work of novel is Yanti (2016) that the objectives of her research discussed about Ecranization processes between the novel 99 Cahaya Di Langit Eropa and its film adaptation and the result concluded that there lot of differences of the plot, setting and character in novel and its film adaptation 99 Cahaya Di Langit Eropa.

This research discussed the ecranization in which it is the process of transforming the story of a literary work such as novel into a film and in the novel story used the writing which transformed into a form of image and sound that is put together. In addition, nowadays a lot of literary works such as novels are made into films, so they can be compared with the process of ecranization, then comparing the ecranization literary work will make the viewers be satisfied or some not. This research focused on Murder on the Orient Express to be analyzed because the research found that there are many ecranization term processes in the novel and its film adaptation. In addition, Murder on the Orient Express is bestseller's novel and this novel is one of Agatha Christie's Favorite because it was a new idea for a plot. The film also played by famous actors and actresses such as Johnny Depp, Penelope Cruz, Daisy Ridley and etc. Furthermore, this novel has not been conducted yet by any researcher.

\section{METHOD}

This Research used descriptive-qualitative method to analyze ecranization processes in terms of plot, character and setting can be found in the novel of Murder on the Orient Express into its film adaptation because the object of analysis are novel and film by describing the facts and followed by analysis and to produces descriptive data in the form 
of written and verbal words is in qualitative research used. This research is conducted based on several steps of following data follows: Reading novel Murder on the Orient Express by Agatha Christie to understand the story, watching film adaptation Murder on the Orient Express by Kenneth Branagh to understand the story, identifying the character in the novel and comparing to its film adaptation, differentiate the character to the form of reduction, addition, and variation of change between the novel and its film adaptation. This research uses several techniques to analyze the data as follows Classifying all of the data based on Eneste's Ecranization Processes reduction, addition, and variation change, analyzing and classifying all of the data of reduction, addition, and variation change from novel to its film adaptation, drawing a conclusion from the analysis.

\section{RESULTS AND DISCUSSION}

The result of the analysis about ecranization processes, reduction, addition, and variation of change, in terms of character was found there are reduction, addition and variation of change.

\section{Reduction in Terms of Character}

"By the step leading up into the sleeping-car stood a young French lieutenant, resplendent in uniform, conversing with a small lean man, muffled up to the ears, of whom nothing was visible but a pinktipped nose and the two points on a upward curled moustache." (Page 3)

In the novel said that there is a young French lieutenant who was talking with a small man in the step leading up into the sleeping-car who looks muffled up to the ears, of whom nothing was visible but a pinktipped nose and the two points on an upward curled mustache. The young French lieutenant was on duty in a train that M. Poirot was traveling on. In the film a young French lieutenant does not exist. It clearly shows that this data indicates reduction in terms of character, means that this character did not appear in the film. According to Eneste (1991,p.61), "Reduction is process of ecranization where from the novel to the film there are parts that are reduced because both of time is different". The reason of why reduction of character occurs is a character that did not have a very important role to the story line is reduced while considering the film duration.

"It is most peaceful. This coach is empty save for myself and one little Greek doctor. Ah! My friend, what a night! They say there has not been so much snow for years. Let us hope we shall not be held up. I am not too bappy about it, I can tell you." (Page 33)

In this part of the novel told that Poirot has a friend, Greek doctor and when M. Poirot walked in the car accidentally met the Greek Doctor in the same train. Finally, they have a little conversation about the amount of snow falling in the city. The scene in the film Greek Doctor has been reduce by the director due to duration and also the character did not have a very important role to the story line in the film. According to Eneste (1991,p.61), "Reduction is process of ecranization where from the novel to the film there are parts that are reduced because both of time is different". The Greek Doctor character is only as an explanation that M.Poirot has a friend who is a Greek doctor so he has the impression that M. Poirot is very humble and has many friends.

There is worse to come. Dr. Constantine-I forgot, I have not introduced you-Dr. Constantine, $M$. Poirot.'

"The little dark man bowed and Poirot returned it. Dr. Constantine is of the opinion that death occurred at about 1 a.m.

It is difficult to say exactly in these matters,' said the doctor, 'but I think I can say definitely that death occurred between midnight and two in the morning." (Page 45)

In the novel is explained that when Ratchett died, Poirot and Dr. Constantine examined the victim. At that time Poirot began to get acquainted with him. They 
became partners in investigating this case. The scene in the film showed that there is no Dr. Constantine in the film. He is been reduced because of the duration of the film. According to Eneste (1991,p.61), "Reduction is process of ecranization where from the novel to the film there are parts that are reduced because both of time is different".

"Where were you in service before you came to $M$. Ratchett?'

With Sir Henry Tomlinson, sir, in Grosvenor Square.'

'Why did you leave him?'

He was going to East Africa, sir, and did not require my services any longer. But I am sure be will speak for me, sir. I was with him some years." (Page 95)

It was told that Sir Henry Tomlinson employ Masterman. Then he went to East Africa and Masterman began to stop working with Henry. Then Masterman worked for M. Ratchett as his servant in the film Sir Henry Tomlinson does not appear. According to Eneste (1991,p.61), "Reduction is process of ecranization where from the novel to the film there are parts that are reduced because both of time is different". It means that the character has been reduced by the director due to duration and also the character did not have a very important role to the story line in the film.

\section{Addition in Terms of Character}

The Kid in Jerusalem (00:02:53)

The scene shows that when Poirot in Jerusalem, there is a kid who brought eggs for M.Poirot's breakfast in Jerusalem. That character does not exist in the novel. According to Eneste (1991,p.64), "Addition is process of ecranization where from the novel to the film there are parts that are added due to the attractiveness of the story, the character of the plot and setting". This scene was added in the film, because the director wanted to make a creative scene in the film which does not exist in the novel.
The Priest, The Imam and The Rabbi (00:05:25)

The data in the film shows that The Priest, The Imam and The Rabbi have been accused of being a suspect in the theft of a gem by one of police and M. Poirot succeeded in exposing The crime and The Priest, The Imam and The Rabbi proven innocent. That characters do not exist in the novel. According to Eneste (1991,p.64), "Addition is process of ecranization where from the novel to the film there are parts that are added due to the attractiveness of the story, the character of the plot and setting". This scene was added in the film, because the director wanted to make a creative scene in the film which does not exist in the novel.

Chief Police Inspector (00:06:12)

In this part of the film told that the character is a chief police inspector who turns out to be a diamond thief who accuses the religious leader. In the film that character does not appear in the novel. According to Eneste (1991,p.64), "Addition is process of ecranization where from the novel to the film there are parts that are added due to the attractiveness of the story, the character of the plot and setting". This scene was added in the film, because the director wanted to make a creative scene in the film which does not exist in the novel.

\section{The Police Officer (00:06:21)}

It was told in the film, When the case of diamond loss was about to be solved by the detective, Poirot told one of the Jerusalem police officers to bring a bag belonging to the inspector's head to be searched and it turned out that the gem was in his bag and by then all the problems are solved and the culprit is the Chief Police Inspector. This Police Officer assisted Poirot in solving the case. In the film that character does not appear in the novel. According to Eneste (1991,p.64), "Addition is process of ecranization where from the novel to the film there are parts that are added due to the attractiveness of the story, the character of the plot and setting". This scene was added 
in the film, because the director wanted to make a creative scene in the film which does not exist in the novel.

The Captain (00:07:41)

This scene shows that there is the captain on duty in the ship and told Poirot that the suitcase had been loaded into the ship. The captain's name was not explained in the film. When The Captain approached M. Poirot and asked that all the suitcases were already on board. In the film that character does not appear in the novel. According to Eneste (1991,p.64), "Addition is process of ecranization where from the novel to the film there are parts that are added due to the attractiveness of the story, the character of the plot and setting". This scene was added in the film, because the director wanted to make a creative scene in the film which does not exist in the novel.

\section{The Chef Mohammed (00:11:38)}

In this part of the film the detective was in the kitchen at one of the stations to enjoy cuisine because Poirot was very fond of eating sweet food. After that, Poirot met his friend, Mohammed, who accidental to be the chef. Poirot was very fond of the cuisine he made. In the film that character does not appear in the novel. According to Eneste (1991,p.64), "Addition is process of ecranization where from the novel to the film there are parts that are added due to the attractiveness of the story, the character of the plot and setting". This scene was added in the film, because the director wanted to make a creative scene in the film which does not exist in the novel.

\section{The Prostitute (00:12:15)}

In this scene of the film shows that M. Bouc met with M. Poirot with his lady who was a prostitute. They meet in the kitchen and have a little conversation. This prostitute which is the character in the film indicates addition in terms of character because the researcher did not find this character in the novel but in the film. According to Eneste (1991,p.64), "Addition is process of ecranization where from the novel to the film there are parts that are added due to the attractiveness of the story, the character of the plot and setting". The film also showed that there was no indication about his name.

\section{Variation of Change in Terms of Character}

"Debenham was tall, slim and dark-perhaps twentyeight years of age. She wore a dark-coloured travelling dress of same thin material eminently suitable for the heated atmosphere of the train." (Page 8)

The film (00:09:31)

The story told in the novel that Debenham's appearance looked tall and had black skin. In the novel also told that Debenham aged twenty-eight years of age. Meanwhile, the film showed that Debenham's appearance was looked short and had white skin. The difference of character that the novel and the film showed makes a conclusion that this data indicates variation of change in terms of character. Eneste (1991,p. 65) state that "Variation of Change is process of ecranization where from the novel to the film there are parts that are changed with the intention to attract stories, characters and settings". The reason is the director wanted to make a creative scene.

"Presently another person entered the restaurant-car. This was a tall man of between forty and fifty, lean of figure, brown of skin, with hair slightly grizaled round the temples.

'The colonel from India,' said Poirot to bimself.

The newcomer gave a little bow to the girl.

'Morning, Miss Debenham.'

'Good-Morning, Colonel Arbuthnot." (Page 8)

The film (01:19:18)

The novel told that Arbuthnot's appearance looks tall, has brown skin and has slightly gray hair on his temple. In addition, he works as a colonel. Different with the film, Arbuthnot's appearance looks short, has darker skin and shaved hair like colonel and doesn't have gray hair. In addition, he works as a doctor. The difference of character that the novel and the film showed makes a 
Aspriyanto, \& Hastuti, Transformation of a novel Murder on an Orient Express...

conclusion that this data indicates variation of change in terms of character. The reason is the director wanted to make a creative scene and also because of the duration.

'Ab! Mon vieux, but this is an unexpected pleasure,' said a voice behind him.

The speaker was a short, stout elderly man, his hair cut en brosse. He was smiling delightedly.

Poirot sprang up.

M. Bouc.” (Page 15)

The film (00:12:17)

There was a story which told the appearance of M. Bouc appears short with en brosse haircuts. That haircut from French that a closely-cropped male haircut in which the hairs stick upward, like the short bristles of a brush; a crew cut. Meanwhile, in the film M. Bouc has a tall body with neat haircuts. The difference of character that the novel and the film showed makes a conclusion that this data indicates variation of change in terms of character. Eneste (1991,p.65) state that "Variation of Change is process of ecranization where from the novel to the film there are parts that are changed with the intention to attract stories, characters and settings". The reason is the director wanted to make a creative scene.

"His slightly bald head, his domed forehead, the smiling mouth that displayed a very white set of false teeth, all seemed to speak of a benevolent personality.

'Quite ready now, Mr. Rachett.”(Page 16)

The film (00:31:53)

There was a story in the novel which told that Mr. Ratchett's appearance has bald hair, he has domed forehead and he has a very white set of false teeth. In this scene of the film, Mr. Ratchett has hair with crew cut hair with a pomade that makes him look shiny and has a mustache. The difference of character that the novel and the film showed makes a conclusion that this data indicates variation of change in terms of character. Eneste (1991,p. 65) state that "Variation of Change is process of ecranization where from the novel to the film there are parts that are changed with the intention to attract stories, characters and settings". The reason is the director wanted to make a creative scene and also the director want to make a different thing for both of the novel and films.

"At a small table, sitting very upright, was one of the ugliest old ladies he had ever seen. It was an ugliness of distinction-it fascinated rather than repelled. She sat very upright. Round her neck was a collar of very large pearls which, improbable though it seemed, were real. Her hands were covered with rings. Her sable coat was pushed back on her shoulders. A very small expensive black toque was hideously unbecoming to the yellow, toad-like face beneath it.

'That's Princess Dragomiroff,' said M. Bouc in a low tone." (Page 25)

The film (00:19:45)

It was told in the novel, Princess Dragomiroff's appearance is described as having an ugly face that is toad-like face. Also on his neck there was a collar of very large pearls, on her hands were covered with rings. She wear sable coat that pushed back on her shoulders and a very small expensive black toque. In the scene film shows that Dragomiroff's appearance depicted an old woman with white hair and her face also does not look like a toad. She only wears a black dress and does not wear a sable coat and black toque. She has a dog that she always carries with her maid. That was why this data indicates variation of change in terms of character, because what the novel told and what the film showed were different. The other reason is the director wanted to make a creative scene.

"His glance shifted to the other side of the carriage. At the far end, against the wall, was a middle-aged woman dressed in black with a broad expressionless face. German lady's maid.'(Page 27)

"Ah, well,' said Poirot, picking up the last passport,'to the final name on our list. Hildegarde Schmidht, lad's maid." (Page 157)

The film (01:02:26)

There was a story in the novel which told that Dragomiroff have a maid, her name 
is Hildegarde Schmidt. Meanwhile, in the scene of the film Dragomiroff's maid was named Fraulein Schmidt. It means that data included variation of change because the character in the novel and the film different. Eneste (1991,p.65) state that "Variation of Change is process of ecranization where from the novel to the film there are parts that are changed with the intention to attract stories, characters and settings". Besides that, he director wanted to make a creative scene. Also the director want to make a different thing for both of the novel and films.

'Edward Henry Masterman.'

'Your age?'

Thirty-nine." (Page 90)

The film (00:14:38)

In the novel, Mr. Ratchett has a valet namely thirty-nine-year-old Edward Henry Masterman. In the movie shows differently, Masterman looks older and has an age of around fifty and always wears a black hat It means that data included variation of change because the character in the novel and the film different. Eneste (1991,p.65) state that "Variation of Change is process of ecranization where from the novel to the film there are parts that are changed with the intention to attract stories, characters and settings". Besides that, the director wanted to make a creative scene and also the director want to make a different thing for both of the novel and films.

'Ab! Here we are. Greta Oblsson, age forty-nine.' $M$. Bouc gave directions to the restaurant attendant, and presently the lady with the yellowish-grey bun of hair and the long mild sheep-like face was ushered in." (Page 107)

The film (00:55:57)

There was a story in the novel which told that there is a Swedish lady was named Greta Ohlsson forty-nine years old. Wearing a yellow bun on his head and his face looks like a sheep. Meanwhile, in the scene of the film the Swedish woman's name was changed to the Pilar Estravados. At his appearance he did not use a yellow bun on his head. It means that data included variation of change because the character in the novel and the film different. Eneste (1991,p.65) state that "Variation of Change is process of ecranization where from the novel to the film there are parts that are changed with the intention to attract stories, characters and settings". Besides that, he director wanted to make a creative scene and look different from the novel and also the director want to make a different thing for both of the novel and films.

"There was no doubt that Count Andrenyi was a fine-looking man seen face to face. He was at least six feet in height, with broad shoulders and slender hips. He was dressed in very well-cut English tweeds, and might have been taken for an Englishman had it not been for the length of his moustache and something in the line of the cheek-bone." (Page 121)

The film (00:14:48)

There was a story which told that Count Andrenyi appearance has a charming face. He was at least six feet in height, with broad shoulders and slender hips. He was dressed in very well-cut English tweeds and he has a moustache. In the scene of the film shows differently, Count Andrenyi has a sharp face that looks fierce. In addition, he does not have a mustache on his face. His face looks clean without a mustache with shiny hair. It means that data included variation of change because the character in the novel and the film different. Eneste (1991,p.65) state that "Variation of Change is process of ecranization where from the novel to the film there are parts that are changed with the intention to attract stories, characters and settings". Besides that, he director wanted to make a creative scene.

His face beamed. It was a typical Italian face, sunny looking and swarthy.

"He spoke French well and fluently, with only a slight accent.

'Your name is Antonio Foscarelli?'

'Yes, Monsieur." (Page 145) 
The film (56:28)

In this part of the novel told that Antonio Foscarelli has a face like beamed. It was a typical Italian face, sunny looking and swarthy. Meanwhile, the film showed that Antonio is a tall man and has a mustache. In the film also here is a change of name, from Antonio Foscarelli to Biniamino Marquez. Eneste (1991,p.65) state that "Variation of Change is process of ecranization where from the novel to the film there are parts that are changed with the intention to attract stories, characters and settings". It means that data included variation of change because the character in the novel and the film different. Besides that, he director wanted to make a creative scene.

\section{CONCLUSION}

Based on the results and discussions about processes of ecranization in terms of plot, setting and character in the novel entitled Murder on the Orient Express written by Agatha Christie into the film entitled Murder on the Orient Express directed by Kenneth Branagh that using Eneste's theory processes of ecranization. The researcher concluded that the processes of ecranization of Murder on the Orient Express the novel and its film adaptation in terms of character are concluded there are reduction, addition, and variation of change. Reduction of character carried out following the plot in a film that does not show several stories so that the character is automatically reduced. The addition of characters is also done because it follows the plot in the film. The plot in the film show many additional stories so it is also required to bring up additional characters that are not found in the novel. Variation of change in both of novel and film occurred because the director also wants to make a difference in both and also in variation of change in this plot does not make a difference at the main of the story.

\section{REFERENCES}

Aderia, P. (2012). Ekranisasi Novel ke Film Surat Kecil Untuk Tuhan karya Agnes Davonar. Thesis. Universitas Negeri Padang. Padang:

Christie, A. (2019). Christie's Favorite Novel. https://www.agathachristie.com/abou t-christie/christies-favourite-christie.

Accessed on April 08, 2019.

Corrigan, T. (1999). Film and Literature: an Introduction and Reader. New Jersey: Prentice Hall.

Eneste, P. (1991). Novel dan Film. Nusa Tenggara Timur: Penerbit Nusa Indah.

Istadiyantha. (2017). Ecranisation, From Textual Tradition To Cinema: The Infidelity Against The Vaues Of Literary Writing?. Humanus Journal, 16(1), 83-92

McFarlane, B. (1996). Novel to Film: an introduction to the theory of adaptation. Oxford: Clarendon Press.

Nurgiyantoro, B. (2015). Teori Pengkajian Fiksi. Yogyakarta: Gadjah Mada University Press.

Praharwati, D. W., \& Romdhoni, S. (2015). Ekranisasi Sastra: Apresiasi Penikmat Sastra Alih Wahana. Buletin Al-Turas. Pp 267-285. ISSN 0853-692

Pratista, H (2008). Memahami Film, Yogyakarta: Homerian Pustaka.

Yanti, D. S. (2016). Ekranisasi Novel ke Bentuk Film 99 Cahaya Di Langit Eropa Karya Hanum Salsabiela Rais dan Rangga Almahendra. Yogyakarta: Universitas Negeri Yogyakarta. 